\title{
“Welcome, o life!": O Künstleroman de James Joyce como galho morto do Bildungsroman
}

\author{
Hêmille Raquel Santos Perdigão* \\ It is an arabesque that may be taken as a miniature for the \\ late Bildungsroman as a whole: every tree has its dead \\ branches, and this, alas, was one of them. \\ Franco Moretti, The Way of the World
}

Resumo: O presente trabalho defende que o Bildungsroman se estendeu até o século XIX, porém não sobreviveu às mudanças do século XX. Para isso, apresenta a leitura de trechos dos romances O Pai Goriot, de Balzac, e Um Retrato do Artista quando Jovem, de Joyce. A conclusão é que há, no primeiro, as características do Bildungsroman e, no segundo, ao contrário, tem-se uma regressão do protagonista que, gradativamente, rejeita a realidade.

Palavras-chave: Bildungsroman. Künstleroman. Regressão. Realidade.

Abstract: The present work defends that the Bildungsroman lasted until the nineteenth century, but it has not survived during the twentieth century. In order to do that, it is present a reading of the excerpts of the novels Le Père Goriot, of Balzac, and A Portrait of the Artist as a Young Man, of Joyce. The conclusion was that there are, on the first, characteristics of the Bildungsroman and, on the second, conversely, there is a regression of the protagonist that, gradually, rejects the reality.

Keywords: Bildungsroman. Künstleroman. Regression. Reality.

Résumé: Le présent travail explique que le Bildungsroman s'est prolongée jusqu'au XIXe siècle, mais n'a pas survécu à le XXe siècle. Pour cela, ce travailfournit quelques extraits des romans Le Père Goriot, de Balzac, et Portrait de l'artiste en jeune homme, de Joyce. Il y a, dans le premier roman, caractéristiques du Bildungsroman et, dans le second, contrairement, il y a une regréssion du protagoniste qui refuse la realité progressivement.

Mots-clès: Bildungsroman. Künstleroman. Régression. Réalité.

\footnotetext{
* Mestranda em Letras da linha de pesquisa Linguagem e Memória Cultural do Programa de PósGraduação em Letras: Estudos da Linguagem da Universidade Federal de Ouro Preto. http://orcid.org/o000-0002-7832-5572
} 
O Bildungsroman é a denominação dos romances que narram a jornada de aprendizagem de um personagem ao longo do tempo, tendo como principal exemplo a obra de Goethe Os anos de aprendizagem de Wihelm Meister. O modelo de Goethe foi reproduzido por outros autores, como Jane Austen, Stendhal e Balzac. Há aqueles que defendam que os romances de formação se estenderam até o século XX, todavia, no presente trabalho, defendo que esse século, ao contrário, marca a crise deles. Para tal, apresento uma análise comparativa dos romances O Pai Goriot, de Balzac, e Um Retrato do Artista quando Jovem, de James Joyce, apontando as características do Bildungsroman ainda presentes na obra do século XIX e que não reaparecem na do século XX.

O Bildungsroman se adaptou às transformações do tempo. $\mathrm{O}$ romance de formação balzaquiano, em função de estar em um diferente contexto histórico, naturalmente se difere dos de seus antecessores Goethe, Austen e Stendhal. Há, nos jovens balzaquianos, a ambição por sucesso que os move. No romance, tal comportamento é tratado como um impulso natural da idade e da época, visto que, na França de meados do século XIX, uma ascensão individual na sociedade passa a ser algo possível. Em seu processo para alcançar suas ambições, o jovem balzaquiano se depara com inversões de valores: o que para sua família era um vício, na sociedade parisiense pode não o ser. O primeiro e mais importante aprendizado do protagonista é que não há, necessariamente, a extrema oposição entre vícios e virtudes. Essas denominações são móveis, assim como a própria posição do indivíduo na sociedade. Classificar algo como virtude ou vício e não mudar essa classificação impedirá, consequentemente, a mudança de posição do personagem na sociedade parisiense.

As with money, the fascination of social mobility is in its boundlessness: it is not a question of reaching 'a' position, no matter how high (Napoleon), but of the possibility to become 'anything'. It is the euphoria of an 'open' society, where everything is relative and changing (MORETTI, 200o, p. 131).

De fato, na sociedade balzaquiana, tudo é relativo e tudo muda. O vício não é mais um ponto de partida, assim como a virtude não é mais o ponto de chegada, estando ambos separados por uma longa estrada de aprendizagem. O que há é um caminho no 
qual vício e virtude se mesclam e, até o personagem completar a sua jornada, tudo mudará, até mesmo seu ponto de chegada.

A receita de Balzac sobre a aquisição de sabedoria do jovem deixa de ser válida no século posterior. "But problems change and old solutions stop working." (MORETTI, 2000, p. 230), explica Moretti. No século XX, o problema da ascensão social é substituído pelo problema da extinção da concepção da idade adulta como sábia. Consequentemente, extingue-se a ideia da aprendizagem do jovem até se tornar um adulto.

\begin{abstract}
In the nineteenth century, the wisdom of adults had been a constant, critical counterpoint to the hero's adventures. But from Mann onwards countless stolid professors will suggest that, as soon as they become professional teachers, adults have nothing left to teach. Youth begins to despise maturity, and to define itself in revulsion from it. Encouraged by the internal logic of the school - where the outside world disappears, while grades overdevelop the sense of the slightest age difference - youth looks now for its meaning within itself: gravitation further and further away from adult age, and more toward adolescence, or preadolescence, or beyond. If twentieth-century heroes are as rule younger than their predecessors, this is so because, historically, the relevant symbolic process is no longer growth but regression. The adult world refuses to be a hospitable home for the subject? Then let childhood be it (MORETTI, 2000, p. 231).
\end{abstract}

Os adultos eram, majoritariamente, pessoas que abusavam da autoridade e que desprezavam as particularidades de cada criança, o que fez com que, nos romances, houvesse uma aversão, por parte dos protagonistas, a se igualarem aos adultos já conhecidos, e assim, uma tendência à regressão para a adolescência ou até mesmo para a infância.

But the world of the late Bildungsroman has solidified into impersonal institutions, while youth has become more vulnerable, and reluctant to grow. With a shift in narrative agency, opportunities turn into accidents: kernels are no longer produced by the hero as turning points of his free growth - but against him, by a world that is thoroughly indifferent to his personal development (MORETTI, 2000, p. 233).

A desatenção ao desenvolvimento pessoal aparece muito nos romances do século $\mathrm{XX}$, nos quais os personagens com aspirações artísticas protagonizam cenas de 
incompreensão por parte dos adultos. Um exemplo disso está em Um Retrato do Artista quando Jovem, de James Joyce.

The idea that youth 'naturally' develop into adulthood had apparently become so unconvincing that Joyce inverted Goethe's trajectory, abandoning the Bildungsroman for the earlier form of the Künstleroman (the artist's novel), where growth and independence are the prerogatives of an exceptionally gifted minority (MORETTI, 2000, p. 271).

Isso fica explícito no próprio título do romance, em que há a denominação do protagonista, Stephen Dedalus, como artista. O desenvolvimento dele se dá pela assunção de sua vocação artística, mas se pensarmos na ideia de adulto como aquele que entende a realidade, o personagem aparenta ser mais adulto no início do romance do que no fim.

Grande parte do enredo de Joyce se desenvolve em instituições católicas nas quais o artista em potencial estudou. Em função disso, há cenas permeadas de sermões religiosos com censuras e promessas de inferno àqueles que pecarem, mesmo que em pensamentos. Para além dos colégios católicos, há cenas no ambiente doméstico, que evidenciam os conflitos entre seus parentes envolvendo religião e política. As palavras dos sermões e das brigas assombram o garoto até um ponto do romance em que ele despreza tanto o Catolicismo quanto o nacionalismo irlandês. Esse desprezo ao mundo adulto acarreta, no protagonista, a recusa à própria realidade.

\footnotetext{
The work of art for Stephen is supremely autonomous, cut loose from all relationship to reality; and this is pretty much the state which he wishes to achieve for himself. [...] If you want to transcend the real world, you have to pay the price of doing so; and this, in the case of the artist, means the sweated labour of immersing yourself in the place in order to gather it into the eternity of art (EAGLETON, 2005, p. 303).
}

Eis uma imensa diferença entre o Künstleroman e Bildungsroman. Em O Pai Goriot, de Balzac, o protagonista Rastignac apreende melhor a realidade no final do romance do que no início, visto que ele percebe que a Paris na qual ele está inserido difere da que ele imaginava. A aquisição de sabedoria do personagem se dá através do convívio com adultos: a família, os amigos, a alta sociedade, os livros e até mesmo o vilão Vautrin, que lhe ensinam o que é a realidade. Colocando em uma balança tudo o que lê, 
ouve e vê, Rastignac é um personagem que se torna sábio e maduro no decorrer das páginas. O próprio narrador balzaquiano elogia o seu protagonista:

Sem suas curiosas observações e a habilidade com que ele [Rastignac] se soube conduzir nos salões de Paris, esta narrativa não teria sido colorida com os tons preciosos que ela deva, sem dúvida, a seu espírito sagaz e a seu desejo e desvendar os mistérios duma situação espantosa, tão cautelosamente oculta pelos que a criaram como pelos que sofrem seus efeitos (BALZAC, 1949, p. 21).

No início, Rastignac dedicava-se aos estudos de Direito, vendo ser este o meio de alcançar seus objetivos de melhoria de vida. Porém, na primeira visita à sua cidade natal, após ter conhecido, mesmo que à distância, a alta sociedade parisiense, o estudante tem um estranhamento de sua própria família:

Suas ilusões de criança e suas ideias provincianas haviam desaparecido. Sua inteligência modificada e sua ambição exaltada permitiram-lhe ver claramente as coisas na casa paterna, no seio da família. O pai, a mãe, dois irmãos, duas irmãs e uma tia cujos haveres consistiam em pensões, viviam nas reduzidas terras de Rastignac. Era uma propriedade cujos rendimentos iam a três mil francos, sujeitos às incertezas das explorações dos vinhedos e da qual, no entanto, era preciso extrair cada ano mil e duzentos francos para ele. A constatação daquela penúria constante, que generosamente lhe ocultavam, a comparação que foi obrigado a estabelecer entre as irmãs, que lhe pareciam tão belas na infância, e as mulheres de Paris, que concretizavam o tipo de beleza com que sonhava, o futuro incerto dessa família que contava com ele, a parcimoniosa atenção com que viu armazenar os produtos mais insignificantes e o fato de fazerem o vinho para a família com o bagaço do lagar, uma infinidade de circunstâncias que seria inútil consignar aqui decuplicaram seu desejo de vencer e deram-lhe sede de honrarias e, como acontece às almas grandes, ele quis, em primeiro lugar, dever tudo ao seu próprio mérito (BALZAC, 1949, p. 36).

É interessante destacar que o mínimo contato com a sociedade já permitiu a Rastignac deixar de enxergar uma ilusão e passar a ver, de fato, a realidade da sua família. A sua visão antes de Paris era uma ilusão de uma criança. Depois de Paris, começa o seu processo de ver as coisas como adulto. O início do conhecimento da realidade é o incentivo para o jovem desejar sua ascensão, a qual depende justamente de adentrar mais a sociedade parisiense. 
O termo criança é usado para se referir a Rastignac no início de sua trajetória. Em uma conversa com o rapaz, uma parente distante, a senhora de Beauséant, a qual estava magoada com a falta de sinceridade do seu amante, o faz a seguinte pergunta:

- Seria capaz de matar uma pessoa, por mim?

- Até duas! - replicou Eugênio.

- Criança! Sim, você é uma criança - disse ela, reprimindo as lágrimas. - Você, sim, é capaz de amar sinceramente! (BALZAC, 1949, p. 66).

A dama o chama de criança por ver nele uma inocência que chega até a emocionála. Ser criança, então, está associado à crença no amor sincero, incondicional, inconsequente e até mesmo submisso. Posteriormente, em conversa com o vilão Vautrin, Rastignac é chamado de criança novamente. Vautrin estava discursando, em tom pedagógico, sobre a realidade, ao que o estudante de Direito responde com o seguinte pedido ao seu interlocutor:

- Não diga mais nada. Não quero ouvir mais nada, pois assim o senhor me faria duvidar de mim mesmo. Neste momento, o sentimento é toda a minha sabedoria.

- Como quiser, bela criança. Pensei que você fosse mais forte. - disse Vautrin (BALZAC, 1949, p. 100).

Após ouvir as palavras de Vautrin, por mais difícil que tenha sido, Rastignac revela que houve ali algum aprendizado: "Em duas palavras, esse bandido me disse mais coisa sobre a virtude do que me haviam dito os homens e os livros." (BALZAC, 1949, p. 100). Nesse episódio, ser criança aparece, mais uma vez, relacionado ao sentimento, visto que, ao Rastignac declarar que o sentimento é toda a sua sabedoria, Vautrin o classifica como criança. Além disso, ser criança seria não suportar ouvir verdades e se abalar diante do fato de um vilão estar ensinando sobre virtudes. Ao fim da conversa, entretanto, Rastignac se torna menos criança e mais adulto.

Adiante na narrativa, a inocência que o protagonista tinha desaparece. $O$ Rastignac de meados do romance já percebe que as relações com as damas parisienses, ao contrário de sua expectativa inicial, estão associadas ao poder e não aos sentimentos: “Ter uma amante - pensava - constitui uma posição quase real, é o símbolo do poder.” (BALZAC, 1949, p. 108). Isso mostra que a leitura que o estudante faz, neste ponto do 
romance, é menos infantil que as que ele fizera no início, uma vez que, observando as relações parisienses, ele não se ilude mais com a possibilidade de amores sinceros por parte das notáveis damas parisienses. Isso prova que ele consegue, agora, ler melhor a realidade e, por isso, construirá a narrativa de sua vida com um melhor desfecho.

No final do seu processo de aprendizado, Rastignac afirma: "Por piores que sejam as coisas que te contem do mundo, acredita! Não há Juvenal capaz de descrever o que há nele de horror coberto de ouro e pedrarias." (BALZAC, 1949, p. 210-211). Juvenal é um autor romano do século I d.C. que compôs sátiras invectivas, denunciando os vícios da sociedade. O riso provocado pelos seus versos é classificado, de acordo com os subgêneros do cômico aristotélico, como psógos (ARISTÓTELES, 2017, p. 6o), cuja característica é a "vituperação, a maledicentia," e "aplica-se como deformação não ridícula, que causa horror e dor, pois reproduz a feiura própria dos vícios fortes” (HANSEN, 2006, p. 95). O autor escolhido por Rastignac como referência de mais fiel à reprodução da realidade é justamente um que trata de vícios, temática muito presente nos próprios livros de Balzac. Trata-se aí do final do processo de aprendizagem do protagonista, quando ele aprendeu, comparando suas leituras de livros e do mundo, o quão maldosas podem ser as pessoas. É importante lembrar que, no início do romance, ele mal conseguia ouvir as verdades trazidas por Vautrin por serem mais cruéis do que o aquilo que ele já havia lido e ouvido. Já agora, ele não só é capaz de ouvir e ler verdades, mas ele próprio as professa.

O final da jornada de crescimento de Rastignac, representado pela cena final de O Pai Goriot, é marcada pela sua contemplação de Paris de um ponto acima da cidade:

Ficando só, Rastignac encaminhou-se para a parte alta do cemitério e de lá viu Paris, tortuosamente deitada ao longo das duas margens do Sena, onde as luzes começavam a brilhar. Seus olhos fixaram-se quase avidamente entre a coluna da praça Vendôme e a abóbada dos Inválidos, no ponto em que vivia aquela bela sociedade na qual quisera penetrar. Lançou àquela colmeia sussurrante um olhar que parecia sugar-lhe antecipadamente o mel e proferiu esta frase suprema:

- E agora, nós!

E como num primeiro ato de desafio à sociedade, Rastignac foi jantar à casa da Sra. De Nucingen (BALZAC, 1949, p. 230). 
Rastignac contempla a sociedade da parte alta do cemitério de modo a ter uma visão ampla de Paris, o que representa o conhecimento total, diferente da visão parcial de criança que ele tinha no início. Ao dizer "Agora nós", Rastignac, no final de sua formação, se sente adulto o suficiente para se dirigir a qualquer pessoa daquele meio. Ao invés de um afastamento da sociedade na qual ele identificou tantos vícios, ele continua inserido nela, o que se deduz da sua decisão de jantar na casa de uma das damas parisienses. Dessa forma, vê-se que a sociedade e a realidade são intrínsecas ao Bildungsroman balzaquiano, não devendo, portanto, ser excluídas ao fim dele. O fim do processo indica, justamente, a sabedoria de estar naquele meio e viver nele com sabedoria, sem sentimentalismo, sem medo das verdades, enxergando coisas e pessoas como realmente são, e não como aparentam ser.

Em Um Retrato do Artista quando Jovem, ao contrário de em O Pai Goriot, temse, no início da trajetória, um mundo indiferente ao desenvolvimento do protagonista, e, no fim, um protagonista indiferente ao mundo. Ocorre uma regressão do personagem, no que tange ao conhecimento da realidade. No início do romance, o pequeno Stephen Dedalus apreende melhor a realidade do que o Rastignac das primeiras páginas de Balzac:

\begin{abstract}
Suas tardes eram livres; e ele as passava com uma tradução esfrangalhada de $O$ conde de Monte Cristo. A figura daquele vingador das trevas representava em sua mente tudo o que tivesse ouvido ou deduzido na infância a respeito do que fosse estranho e terrível. À noite montava na mesa da sala de estar uma imagem da fabulosa caverna da ilha com decalques e flores de papel de seda colorido e tiras do papel prata ou ouro em que vem embalado o chocolate. Quando tinha desmontado esse cenário, cansado de seu brilho, vinha-lhe à mente a luminosa imagem de Marselha, de treliças ensolaradas, e de Mercedes. Perto de Blackrock, na estrada que leva às montanhas, ficava uma casinha caiada em cujo jardim cresciam muitas roseiras: e nessa casa, ele se dizia, morava uma outra Mercedes. Tanto no caminho de ida quanto no de volta para casa ele media a distância por esse marco: e em sua imaginação vivia uma longa sequência de aventuras, maravilhosas como as do próprio livro, em cuja parte final surgia uma imagem dele mesmo, já mais velho e mais triste, num jardim enluarado com Mercedes que por tantos anos recusara seu amor, e com um gesto de recusa tristemente orgulhoso, dizendo:

- Madame, eu nunca como uvas moscatel (JOYCE, 2016, p. 83-4).
\end{abstract}

Stephen, como leitor, tem muitas imaginações a partir de $O$ Conde de Monte Cristo. Ele identifica o vingador do livro com as coisas terríveis que já ouvira e, mesmo 
as aventuras, ele transfere para sua imagem. Entretanto, o próprio personagem tem ciência de ser essa imaginação algo infantil, tanto que o fim do devaneio é sempre a figura de si mesmo velho, o que mostra a tendência de Stephen a retornar à realidade após a leitura e não misturar vida e romance. Nessa cena, o protagonista de Joyce é criança pela idade, ao passo que o de O Pai Goriot o é, no início do romance, pela interpretação que tem da vida, uma vez que, no "mundo da criança não há distinção clara entre realidade e aparência. [...] Não existe divisão rígida entre fantasia e realidade, verdade e impostura.”. (GOMBRICH, 2007, p. 84). De fato, Rastignac, no início, não consegue fazer tal distinção. Já Stephen Dedalus o faz quando criança.

Conforme apresentado, a crise do romance de formação está ligada à descrença e decepção com adultos. Um exemplo disso está na cena em que o estudante Stephen é punido injustamente pelo prefeito de disciplina de sua escola. Tem-se o início do episódio quando o sacerdote, após ter adentrado a sala disposto a fazer uso da palmatória e já ter se dirigido a um outro aluno, nota que Dedalus não está escrevendo:

- Você, garoto, quem é você?

O coração de Stephen deu um repentino salto.

- Dedalus, senhor.

- Por que é que você não está escrevendo, como os outros?

- Eu... os meus...

- E, de medo, não pôde falar.

- Por que é que ele não está escrevendo, Padre Arnall?

- Ele quebrou os óculos - disse o Padre Arnall - e eu o isentei de escrever a tarefa.

-Quebrou? Que é que eu estou ouvindo? Que história é essa? Como é mesmo o seu nome?

- Dedalus, senhor

- Saia pra cá, Dedalus. Seu trapaceirozinho preguiçoso. Estou vendo o fingimento na sua cara. Onde quebrou você os seus óculos?

Stephen tropeava no meio da sala, cego de medo e de atrapalhação.

- Onde foi que você quebrou os seus óculos? - tornou a perguntar o prefeito dos estudos.

- Na pista onde tem cinza, senhor.

- Olá! Na pista, hem? - exclamou o prefeito dos estudos. - Eu conheço essa manha.

Stephen ergueu os olhos com espanto e viu, por um instante, a cara macilenta e já avelhantada do Padre Dolan; uma cabeça raspada, cor de cera, com lanugens dos lados; os aros de aço dos seus óculos, e aqueles seus olhos sem cor olhando através dos vidros. Por que disse ele que conhecia aquela manha?

- Seu vadio, pequeno preguiçoso! - exclamou o prefeito dos estudos. - Quebrei os meus óculos! Já é muito velha essa manha! Ponha já a mão pra fora! (JOYCE, 1971, p. 48). 
Stephen assustou-se com o chamado da autoridade e mal conseguiu falar, deixando que padre Arnall respondesse por ele o questionamento do prefeito de disciplina. O fato de o garoto não conseguir ler sem auxílio de óculos indica sua incapacidade de ver as coisas por si só. Nessa idade, ele ainda não conseguia ver o mundo, julgar o que era puro ou impuro sem se pautar em sermões e ensinamentos dos padres. Moretti explana a relação entre as punições injustas no local de ensino e a crise do Bildungsroman:

\begin{abstract}
But inside... this is the trouble with the school: it teaches this and that, stressing the objective side of socialization - functional integration of individuals in the social system. But in so doing it neglects the subjective side of the process: the legitimation of the social system inside the mind of individuals, which had been a great achievement of the Bildungsroman. What the school deals with are means, not ends; techniques, not values. A pupil must know his lesson, but he doesn't have to believe in its truth. Convincing the subject that what he must do is also symbolically right is, however, exactly what modern socialization is all about. If this does not happen, and shared values are replaced by sheer coercion (how many arbitrary and unfair punishments in these novels!) the individual will hardly feel at home in his world, and socialization will not be fully accomplished (MORETTI, 200o, p. 230-231).
\end{abstract}

A falta de compreensão, por parte das autoridades escolares, da individualidade dos alunos se comprova na sequência à punição sofrida por Stephen na sala de aula. Incentivado pelos colegas, a criança toma a decisão de contar ao reitor que foi punido injustamente por não fazer as atividades de latim. $\mathrm{O}$ reitor incialmente pergunta a Stephen se ele esclareceu ao prefeito o que havia acontecido com seus óculos e minimiza a punição sofrida pelo menino, respondendo apenas que iria conversar com Dolan. Tempos depois, porém, o reitor conta o ocorrido ao pai de Stephen como se fosse um fato cômico, não atribuindo a devida importância de ter acontecido uma agressão física ao aluno, além da humilhação diante dos colegas, por razões injustas, envolvendo falsas acusações. O reitor e outros padres riem do caso, e o pai, também não compreendendo a importância do fato para o filho, reporta à esposa:

O sr. Dedalus imitou o tom mole e anasalado do provincial.

- O padre Dolan e eu, quando eu contei tudo na hora do jantar, o padre Dolan e eu rimos muito. "É melhor você se cuidar, Dolan", eu disse "ou o pequeno Dedalus vai te mandar tomar duas de nove." Nós rimos até não poder mais. Hahaha! 
O sr. Dedalus virou para a esposa e acrescentou com sua voz normal:

- Isso mostra o jeito que eles têm com os meninos de lá. Ah, os jesuítas sem sombra de dúvida, pela diplomacia!

Ele retomou a voz do provincial e repetiu:

- Eu contei a todos eles na hora do jantar, e o padre Dolan e eu e todo mundo riu que se fartou. Hahaha! (JOYCE, 2016, p. 96).

O fato de os padres terem rido de Stephen permanece em sua memória. A cena seguinte é a da noite de uma peça teatral sobre Pentecostes, durante a qual o estudante, não coincidentemente, fixa o olhar no rosto sorridente de um padre:

A noite da peça teatral da semana de Pentecostes tinha chegado, e Stephen da janela do camarim olhava para o pequeno gramado atravessado por fileiras de lanternas chinesas. Ficou olhando os visitantes descerem os degraus da casa e entrarem no teatro. Porteiros com roupa de gala, antigos alunos do Belvedere, ficavam à toa em grupinhos perto da entrada do teatro e faziam os visitantes entrar cheios de cerimônia. Sob o súbito clarão de uma lanterna ele pôde reconhecer o rosto sorridente de um padre (JOYCE, 2016, p. 96)

Num canto escuro da capela, no lado do evangelho do altar, uma senhora robusta estava ajoelhada em meio às copiosas saias negras. Quando levantou, uma figura vestida de rosa com uma peruca loura de cachinhos e um chapéu de palha antiquado, com negras sobrancelhas feitas a lápis e bochechas delicadamente maquiada de vermelho e empoadas revelou-se. Um murmúrio baixo de curiosidade percorreu a capela diante da descoberta dessa figura feminina. Um dos bedéis, sorrindo e acenando com a cabeça, aproximou-se do canto escuro e, depois de ter feito uma reverência para a senhora robusta, disse agradável:

- Trata-se de uma bela moçoila ou de uma boneca essa sua acompanhante, sra. Tallon?

Então, abaixando-se para espiar o rosto pintado sob a aba do chapéu, ele exclamou:

- Não! Palavra que é de fato o jovem Bertie Tallon!

Stephen em seu posto de junto da janela ouviu a senhora e o padre rirem juntos e ouviu os murmúrios de admiração dos meninos atrás de si enquanto passavam para ir ver o menininho que tinha que fazer sozinho a dança do chapéu. Um movimento de impaciência lhe escapou. Ele deixou cair a borda da cortina e, descendo do banco onde estava de pé, saiu da capela (p. 97-98).

O narrador não especifica quais são os pensamentos de Stephen, mas é possível entender que ver o rosto sorridente do padre faz com que ele se lembre de padre Dolan rindo dele. Por fim, quando o sacerdote e a mulher riem do menino, ele não consegue mais conter o desconforto e sai. $\mathrm{O}$ fato de a mulher, mãe de uma das alunas, rir do filho junto a um sacerdote remete ao diálogo entre seu pai e o reitor. Ao sair, Stephen encontra os amigos, que zombam dele porque Mercedes, a menina de quem ele gostava, poderia estar lá para assistir à peça. Os colegas de Stephen queriam que ele admitisse 
que eles o haviam desmascarado, por terem descoberto que a menina era uma namorada. Ao ouvir os colegas dizendo “Admita”, Stephen se lembra de um episódio semelhante, anos antes, em que os colegas usaram o mesmo verbo, no mesmo modo verbal, para que ele admitisse ser herege. A análise da repetição da vida, pelo garoto, tem início com uma palavra. Em ambos os episódios, relacionados pelo menino, a risada aparece; assim como apareceu nas conversas entre os padres, no relato do pai:

Depois de uma última fúria de pancadas ele conseguiu se libertar. Seus algozes dispararam para Jones's Road, rindo e zombando dele, enquanto ele, quase cego por causa das lágrimas, seguira aos tropeços, punhos furiosamente cerrados, soluçante.

Enquanto ainda repetia o confiteor em meio ao riso indulgente de seus ouvintes e enquanto as cenas do pérfido episódio ainda passavam cortante e velozmente por sua mente, ele ficou pensando por que não guardava rancor daqueles que $o$ atormentavam. Não tinha esquecido absolutamente nada da covardia e da crueldade deles, mas lembrar disso tudo não despertava raiva nele. Todas as descrições de amores e ódios ardentes que tinha encontrado nos livros lhe pareciam portanto irreais. [...]

Continuou ali parado com seus dois companheiros ao lado do alpendre ouvindo desligado o que diziam ou as salvas de palmas no teatro (JOYCE, 2016, p. 104107).

Em sua análise das repetições da vida, Stephen diferencia a vida dos livros que lê, percebendo que, na realidade, os sentimentos não têm a mesma intensidade descrita nos romances.

Ao fim da apresentação teatral, Stephen precisava de um momento para romper com a irrealidade da peça em que estava atuando e adentrar sua vida real. Opta, então, por fugir do momento de conversa com a família, que o esperava para o parabenizar pela atuação:

Sem ficar esperando as perguntas do pai ele atravessou a rua correndo e começou a correr desesperadamente morro abaixo. Mal sabia aonde ia. Orgulho, esperança e desejo como ervas maceradas no seu coração evolavam vapores de incensos enlouquecedores diante dos olhos de sua mente. Desceu o morro a passo firme em meio ao tumulto dos vapores subitamente despertados do orgulho ferido e da esperança desabada e do desejo negado. Eles subiam diante de seus olhos angustiados em fumos densos e enlouquecedores e desapareciam acima dele até que por fim o ar ficou limpo e frio mais uma vez. Uma película velava-lhe ainda os olhos, mas eles não ardiam mais. Uma força, aparentada da que muitas vezes fazia a raiva ou o ressentimento se afastarem dele, fez seus passos se acalmarem. Ele se deteve e ficou olhando a escura varanda da morgue e dali levou os olhos para a negra viela calçada de pedra ao 
seu lado. Viu a palavra Lotts no muro da viela e respirou lento o ar pesado e malcheiroso.

"Isso é mijo de cavalo e palha podre.", ele pensou. "É um odor bom de se respirar. Vai me acalmar o coração. Meu coração já está bem calmo. Vou voltar (JOYCE, 2016, p. 111).

Após uma série de devaneios e de uma imersão em uma peça teatral, Stephen tenta recuperar a noção de realidade. $\mathrm{O}$ modo dele de voltar à realidade é pensar em mijo de cavalo e palha podre, elementos que o acalmam. Stephen percebe a realidade de dois modos: analisando as repetições de sua vida e se prendendo a coisas fétidas e comuns. Como se percebe, o conceito de realidade da criança não está associado a sentimentalismos e coisas belas, como o de Rastignac no início de O Pai Goriot.

Vejamos outro momento em que Stephen percebe a realidade analisando as repetições da sua vida, e a mudanças que há a cada vez que uma cena se repete:

\begin{abstract}
Stephen estava uma vez mais ao lado do pai no canto de um vagão de trem em Kingsbridge. Estava viajando com o pai para Cork via correio noturno. Enquanto o trem saía fumegante da estação ele lembrou de seu espanto infantil de anos antes e de cada evento em seu primeiro dia em Clongowes. Mas agora não sentia espanto. Via escaparem de seu campo de visão as terras que escureciam, os postes silentes do telégrafo passarem velozes a cada quatro segundos, as pequenas estações reluzentes, ocupadas por poucas sentinelas silentes, que o trem deixava em seu rastro e rebrilhavam um momento no escuro como grãos flamejantes no rastro de um corredor.

Ouvia sem dar muita importância às evocações de Cork que o pai fazia e às cenas de sua juventude, uma história interrompida por suspiros ou goles de sua garrafinha de bolso toda vez que aparecia a imagem de algum amigo morto ou toda vez que quem evocava recordava de repente o propósito de sua visita real (JOYCE, 2016, p. 111-112).
\end{abstract}

Stephen analisa, mais uma vez, as repetições de sua própria vida. Lembra que a viagem já aconteceu antes, porém agora ele lida melhor com o medo. Também seu pai analisa as repetições de sua própria vida, os fatos da juventude, e precisa de um esforço para se recordar do "propósito da vida real”.

Em seguida, Stephen adentra o passado do pai, indo até a sala onde ele estudara.

Entraram na sala de aula de anatomia onde o sr. Dedalus, com o auxílio do porteiro, foi procurar suas iniciais nas carteiras. Stephen ficou no fundo, deprimido a mais não poder pela escuridão e pelo silêncio da sala e pelo ar que ali restava, de estudo formal e fatigante. Na carteira ele leu a palavra feto entalhada várias vezes na madeira escura e manchada. A inopinada legenda deu 
um susto em seu sangue: parecia sentir a presença dos alunos ausentes da universidade à sua volta e se encolher diante deles. Uma visão da vida deles, que as palavras do pai não tiveram o poder de evocar, a palavra talhada na carteira fez saltar diante dele. Um aluno de ombros largos e bigode estava entalhando as letras com um canivete, compenetrado. Outros alunos estavam de pé ou sentados ao lado dele rindo de sua artesania. Um bateu-lhe no cotovelo. O grandão se virou para ele, de cara fechada. Trajava roupas cinzentas e frouxas e calçava botas marrons.

Chamavam o nome de Stephen. Ele desceu correndo os degraus do anfiteatro para ficar o mais longe possível da visão e, examinando de perto as iniciais do pai, escondeu o rosto enrubescido.

Mas a palavra e a visão cabriolavam diante de seus olhos enquanto ele retraçava seus passos pelo gramado e na direção do portão da universidade. Ficou chocado ao descobrir no mundo lá fora um vestígio do que até então lhe parecia uma moléstia individual e bestial da própria mente. Seus monstruosos devaneios atropelavam-lhe a memória. Eles também tinham saltado diante de seus olhos, súbita e furiosamente, por causa de meras palavras. Ele logo cedera a eles e permitira que varressem e degradassem o seu intelecto, imaginando sempre de onde teriam vindo, de que covil de imagens monstruosas, e sempre fraco e humilde para com os outros, inquieto e enojado consigo quando elas o varriam. [...]

As letras talhadas na madeira manchada da carteira o encaravam, rindo-se de sua fraqueza corpórea e de seus vãos entusiasmos e fazendo ele se detestar por suas próprias orgias loucas e imundas. [...]

Ainda podia ouvir a voz do pai (JOYCE, 2016, p. 116-117).

Nessa cena, uma palavra também é o gatilho dos devaneios de Stephen. Ele relaciona as repetições da vida do pai com as da sua própria vida. Pensou na risada dos alunos e isso remeteu às repetidas gargalhadas das quais ele já teve que ser o motivo. $\mathrm{O}$ jovem faz a leitura da sua vida e da de seu pai e percebe, então, que as risadas são o elemento de repetição delas. Ter a voz do pai ao fundo faz com que Stephen transite para a realidade, não se entregando totalmente ao medo das risadas presentes em seu devaneio:

Stephen ouviu a voz do pai sumir numa risada que era quase um soluço. - Ele era o homem mais bonito de Cork na época, juro por Deus! As mulheres paravam pra ficar olhando ele passar na rua.

Ele ouviu o soluço descer lento na garganta do pai e abriu os olhos com um impulso nervoso. À luz do sol irrompendo súbita em seus olhos transformou o céu e as nuvens num manto fantástico de volumes sombrios com espaços como que lacustres de uma luz rosa profunda. Até seu cérebro estava nauseado e incapaz. Ele mal conseguia interpretar as letras nas placas das lojas. Por seu modo monstruoso de vida ele parecia ter se posto além dos limites da realidade. Nada o comovia nem lhe dizia alguma coisa a respeito do mundo real a não ser que o ouvisse num eco dos gritos enfurecidos que trazia por dentro. Não conseguia reagir a qualquer apelo terreno ou humano, surdo e insensível diante do chamado do verão, da felicidade e da camaradagem. Exausto e desolado pela 
voz do pai. Mal conseguia reconhecer suas próprias ideias, e repetia sozinho mentalmente:

- Eu sou Stephen Dedalus. Estou caminhando ao lado do meu pai que se chama Simon Dedalus. Nós estamos em Cork, Irlanda. Cork é uma cidade. O nosso quarto fica no hotel Victoria. Victoria e Stephen e Simon. Simon e Stephen e Victoria. Nomes (JOYCE, 2016, p. 118).

Abrir os olhos assusta o garoto, e a transição dele para a realidade, ao contrário das cenas em que ele era criança, é mais difícil. Kosik explica serem necessárias chaves para a transição entre os mundos.

O homem vive em muitos mundos, mas cada mundo tem uma chave diferente, e o homem não pode passar de um mundo para o outro sem a chave respectiva, isto é, sem mudar a intencionalidade e o correspondente modo de apropriação da realidade (KOSIK, 1985 , p. 23).

Stephen, com o passar do tempo, começa a ter mais problemas em usar essas chaves de transição entre devaneios e realidade. Em função de o mundo externo estar tão controlado pelas visões de outros, ele chega a pensar que nada o comove na realidade, e, por isso, se coloca na confortável posição de fechar os olhos e viver a sua liberdade interior. Porém, a voz do pai interrompe esse momento e, ao abrir os olhos, a transição se torna mais difícil. Nesse ponto, os devaneios de Stephen prevalecem sobre a realidade, porém momentaneamente, uma vez que o garoto começa a repetir seu nome, numa tentativa de retorno à realidade, mesmo essa lhe sendo pouco atrativa.

Em cena posterior, temos outro exemplo de Stephen Dedalus como leitor da realidade vida. Angustiado com as palavras dos sacerdotes sobre inferno, Stephen tem devaneios, pensando já estar morto e condenado ao terror eterno:

As vozes que ele conhecia tão bem, as palavras comuns, a tranquilidade da sala de aula quando as vozes se detinham e o silêncio era preenchido pelo som do gado que pastava delicadamente enquanto os outros meninos mascavam seu lanche com calma, pacificou sua alma dolorida.

Ainda havia tempo (JOYCE, 2016, p. 156).

O som do gado e as palavras deixam Stephen ciente da realidade, pois pensa que, se pode ouvir tais sons, significa que ainda não está morto. 
Terry Eagleton explica como os sermões sobre o fogo do inferno são determinantes na recusa, por Stephen, do mundo adulto e suas instituições:

The hell-fire sermons in Portrait of the Artist press the senses into the service of the spirit, as the preacher drives home his anti-carnal point with luridly fleshly images. Politics, at least where Irish nationalism is concerned, is also a combination of the mundane and the idealistic; but Stephen finds both dimensions distasteful (EAGLETON, 2005, p. 302).

De fato, os temas do fogo e da visão culminam numa cena que marca o fim da incapacidade de Stephen de enxergar por si mesmo, e também o fim da sua submissão às opiniões dos adultos. $\mathrm{O}$ momento, tão esperado pelo protagonista, começa quando o padre conversa com ele sobre a possibilidade de sua vocação sacerdotal. Stephen ergue os olhos para um sacerdote, cuja instituição representava anos de sua submissão, o que o leva a pensar em seu nome antecedido por um título religioso. Ao associar uma imagem de si mesmo ao título de reverendo, Stephen vê um rosto sem olhos e com ira sufocada. Neste momento, o jovem percebe que prosseguir neste caminho seria equivalente a se condenar a uma cegueira permanente, além de uma contenção eterna dos queimores internos. Ele sente, então, um forte de desejo de caminhar e, durante sua caminhada, encontra uma mulher.

Stephen enxerga a mulher em uma contemplação isenta de opiniões eclesiásticas. Assim sendo, a descrição que ele dá é comparativa a uma ave, que remete à figura cristã do Espírito Santo, rompendo totalmente com a imagem profana da mulher para tornála, pelo contrário, uma figura sagrada:

Subitamente se afastou dela e seguiu através da praia. Todo o seu rosto estava afogueado; todo o seu corpo abrasado; os seus membros tremiam. [...] Os olhos dela o tinham chamado: e a sua alma saltara a tal apelo (JOYCE, 1971, p. 161).

A alma de Stephen, que atende ao chamado, é, justamente, a alma de arista, libertada da opressão dos adultos que não o compreendiam.

In a Rimbaud-like episode of initiation and rebirth - a perfect kernel, in all possible respects - epiphany redeems the meaninglessness of the past. Revealing that Stephen's youth had always had a secret aim - the discovery of 
an artist's 'soul' - and that it has finally achieved it. One could not wish for a better closure for Joyce's ambitious Künstleroman (MORETTI, 200o, p. 241).

Após o episódio da mulher pássaro, Stephen aparece sem influência da visão eclesiástica, de modo que ele consegue erguer o olhar para coisas que antes the eram proibidas. Além disso, não há mais as cenas em que o jovem tem lutas internas, tentando se desprender dos devaneios e se ligar à realidade.

Portrait goes on, and the following chapter, compared to all previous ones, is strikingly blank and pointless. Neither visions nor rebirths here, but idle conversations to kill the time; no menacing institutions, but a banal everydayness; the seer has turned into a young pedant, for whom epiphany is just a tricky philological riddle. (MORETTI, 200o, p. 241)

Em meio ao que Moretti chama de "banal everydayness", há uma frase dita por Stephen e que merece destaque. Já nos fins do romance, o protagonista diz: "No útero virgem da imaginação o mundo fazia-se carne.” (JOYCE, 2016, p. 265). Trata-se de uma analogia à concepção de Jesus no útero virgem de Maria, trocando, na frase, o nome de Maria por "imaginação" e o de Jesus por "mundo". Em alguns momentos do romance, quando a culpa por seus pecados lhe pesava, Stephen se dirigia a Nossa Senhora, por sentir que ela não o repreenderia. Exemplo disso é o seguinte excerto do início da narrativa:

\footnotetext{
Seu pecado, que o toldara das vistas de Deus, deixara-o mais próximo do refúgio dos pecadores. Os olhos dela pareciam observá-lo com mansa piedade; sua santidade, estranha luz que brilhava leve sobre sua carne frágil, não humilhava o pecador que se aproximava dela. Se em algum momento foi impelido a lançar de si o pecado e se arrepender, o impulso que o move foi o desejo de ser seu cavaleiro. Se em algum momento sua alma, reingressando tímida em sua morada depois que o frenesi da luxúria do corpo se acabava, virou-se para ela cujo emblema é a estrela da manhã, clara e musical, que fala do paraíso e infunde a paz, foi quando seus nomes eram murmurados delicadamente por lábios nos quais restavam ainda palavras sujas e vergonhosas, o próprio sabor de um beijo lascivo. (JOYCE, 2016, p. 133).
}

Fica claro que Nossa Senhora era seu refúgio quando ele se sentia julgado por Jesus, o qual the inspirava medo. Com as trocas dos elementos na frase, deduz-se que, agora, Stephen se refugia na imaginação quando sente medo do mundo. Isso indica que, no Künstleroman, ao contrário do Bildungsroman, há uma regressão na leitura da 
realidade pelo protagonista. No início, Stephen tenta se manter preso à sua realidade quando os devaneios lhe amedrontam; no final, ele se entrega à imaginação diante de seus medos. Reafirmo que as frases da parte final de Um Retrato do Artista quando Jovem poderiam ser atribuídas a Rastignac no início de seu aprendizado, ao passo que as frases da parte inicial poderiam ser atribuídas ao personagem balzaquiano no final de sua formação. A evolução do Stephen criança, no início do livro, para o final, se dá pelo abandono da visão eclesiástica e da descoberta de sua aptidão artística. Stephen, porém, se desliga de qualquer outra visão, chegando, no final do livro, a um rompimento com o seu meio. Após a epifania com a mulher à beira da praia, ele não mais depende da opinião de outrem para ver o mundo, mas baseia tudo em suas leituras e interpretações pessoais.

Uma das últimas frases do romance anuncia o encontro com a vida, marcando um desfecho do romance que mais parece com um início: "Bem-vinda, vida, sigo para encontrar pela milionésima vez a realidade da experiência e engendrar na forja de minha alma a consciência incriada de minha raça.” (JOYCE, 2016, p. 309). As boas vindas à vida, dadas por Stephen, se tornam compreensíveis se pensarmos na reaparição do personagem no romance Ulysses. Em uma das cenas, Stephen alega ser a história o pesadelo do qual ele está tentando acordar. "History, as Stephen Dedalus of Ulysses famously remarks, is a nightmare from which he is trying to awaken, and art, one might say, is his alarm clock." (EAGLETON, 2005, p. 281). Conforme explica Eagleton, a vocação artística é, para o personagem de Joyce, um refúgio à realidade. Dessarte, as boas-vindas à vida, no final de Um Retrato do Artista quando Jovem, não são à vida real, mas sim à vida refugiada na imaginação que possibilitará sua produção artística.

A partir dessas leituras, conclui-se que em O Pai Goriot, no século XIX, apesar de não ser uma narrativa aos moldes das de Goethe, havia, sim, características típicas do Bildungsroman. Rastignac, no início do enredo, é dito criança por sua crença inocente nos sentimentos, por sua incapacidade de ouvir e reconhecer as verdades. Ouvindo e lendo distintos posicionamentos sobre vícios e virtudes, o rapaz adquire um conhecimento necessário para lidar com a sociedade. Dessa forma, a sociedade, sobretudo os adultos, são parte do processo de formação balzaquiano e o fim do processo significa justamente a capacidade de bem viver na sociedade. Entretanto, a mudança dos problemas mundiais de um século para o outro exigiram narrativas distintas. Isso explica 
o porquê de Um Retrato do Artista quando Jovem não compartilhar as características do Bildungsroman, como a transformação da criança em um adulto, mas ter características do Künstleroman, com a transformação do jovem em um artista. O romance mostra, no início, uma tentativa, por parte do protagonista, de apreender a realidade e de se desligar dos devaneios. A ideia de realidade, para o Stephen criança, está ligada às repetições da vida, a elementos ordinários e comuns e não às narrativas dos livros, que o garoto reconhece serem irreais. Porém, quando ele apresenta a evolução de ver o mundo por si mesmo, independente de opiniões de adultos e instituições, simultaneamente ele apresenta a regressão de não mais se prender ao real, mas se abrigar no imaginário. Isso evidencia que O Pai Goriot, de Balzac, é um representante do século em que a árvore Bildungsroman ainda possuía galhos vivos enquanto Um Retrato do Artista quando Jovem, ao lado de outros romances do mesmo período, é um galho morto dessa árvore centenária.

\section{Referências bibliográficas}

ARISTÓTELES. Poética. Tradução de Paulo Pinheiro. São Paulo: Editora 34, 2017.

BALZAC, Honoré de. O Pai Goriot. Porto Alegre: Editora Globo, 1949.

EAGLETON, Terry. The English Novel: an Introduction. Oxford: Blackwell Publishing, 2005 .

GOMBRICH, E. H. Arte e Ilusão: um estudo da psicologia da representação pictórica. São Paulo: Martins Fontes, 2007.

HANSEN, J. A. Categorias Epidíticas do Retrato. Revista USP, São Paulo, v.71, p. 85-105, 2006.

JOYCE, James. Retrato do Artista quando Jovem. São Paulo: Abril Cultural, 1971. . Um Retrato do artista quando jovem. São Paulo: Penguin Classics, Companhia das Letras, 2016.

KOSIK, Karel. Dialética do Concreto. Rio de Janeiro: Paz e Terra, 1985. 
MORETTI, Franco. The Way of the World: The Bildungsroman in European Culture. New York: Verso, 2000.

Recebido em 20/04/2020. Aprovado em 19/08/2020. 